\title{
THE BODY OF HISTORY ON PARALLEL STORIES, THE NOVEL BY PÉTER NÁDAS
}

\author{
JUDIT GÖRÖZDI \\ Institute of World Literature, Slovak Academy of Sciences \\ gorozdijudit@panelnet.sk
}

\begin{abstract}
Péter Nádas's novel published in the Hungarian language in 2005 deals with both European and Hungarian history, and validates a very specific view on history. The purpose of this paper is to reflect upon the question of relevance to the text concerning the body/body ideology aspects of Nádas's historical approach. Differing representations of our sensuality in addition to placing the issue into a new context is one of the substantial undertakings of Parallel Stories, which in my opinion is worth approaching in the interrelationship of body-sensuality - body ideologies - history - power-novel structure. In my study, I start out from K. Theweleit's theory, which combines the forceful exercise of power with the ideology of male camaraderie, I then analyse how this approach appears in different text levels, motifs, scenes of Nádas's novel, up to the composition following the "chaos structure".
\end{abstract}

Keywords: contemporary Hungarian literature, historical novel, Péter Nádas, body ideologies, chaos theory

Péter Nádas's novel has been translated into several languages since its publication in 2005, and has attracted a lot of attention not only in Hungary but worldwide, and has been supported by prestigious literary awards and widespread critical interest. The novel describes the history of the twentieth century milling about turbulently in the spirit of the brown and red dictatorship, through parallel narrations of a Hungarian and a German plotline that also represents historical spaces referring to symbolic poles of Central Europe. The richness of the elaborated historical material, the originality of the viewpoints raised, and not least the formulating features of the novel poetics have inspired analyses with the most varied theoretical starting points, but it seems that Nádas's novel is still worth thinking about; there is still plenty to say.

The purpose of this paper is not to analyse the whole text; it wishes to reflect upon the question of relevance to the text concerning the body/body ideology aspects of Nádas's historical approach.

Let us recall some of the most remarkable scenes/storylines of the novel to introduce our train of thought: in March of 1961, three almost naked men experiment with each other, touching each other in ways that border on the natural 
and impudent, love and betrayal, in the locker room of the Lukács Baths. Nine months earlier, on the Margaret Island, homosexual men are pursuing and are being pursued "round and round", and in this partner rotating "roundelay" their physical abilities (especially relating to their genitals) determine their position. In 1945 (and before), in the life of the inmates of the concentration camp near Pfeilen, Germany, it is the radiant power of the beautiful body too that ultimately - in a way that is devoid of all moral considerations - ensures a kind of hierarchical place with a hope for survival (the Kramer - Peix line). Likewise, in a Swiss boarding school for boys at approximately the very beginning of the 1940s, the innocent ten-year-old student must also experience that the sight of his body is the very secret exchange-value in the boy community which helps prevent humiliation and beatings. Meanwhile, at the time of Fascist domination, in an experimental boarding school in Annaberg of Saxony, the body as such is no longer a merely stake of the hidden night life also affecting the public daytime, but is the downright object and purpose of institutional attention.

The otherness of the representation of our sensuality and placing the issue into a new context is one of the substantial undertakings of Parallel Stories, which in my opinion is worth approaching in the interrelationship of body - sensuality body ideologies - history - power - novel structure. Some suggestions:

\section{Sensuality and body ideology}

In the novel, the scientific supervisor of the boarding school in Annaberg that serves for racial biological research is Otmar Freiherr von der Schuer, the head of the Kaiser Wilhelm Institute in Berlin, a high-ranking representative of bio power in Foucault's sense, whose name is hardly different from that of Otmar Freiherr von Verschuer, the scientific father of the Nazi Lebensborn program serving for Aryan eugenics, created by Heinrich Himmler in 1935. Von der Schuer of the novel was socialized in a military male community, and his body view was determined by the collision of his bodily experiences in the First World War with the valid body ideology:

\footnotetext{
“...neither religion nor tradition can explain the shy physical tenderness and cruel physical brutality he had seen and profoundly experienced in water-soaked trenches, among barbed-wire obstacles, in the miserable barracks of military hospitals, and in overheated whorehouses reeking of tobacco in small Galician towns. Everything was beyond what could be measured by any social standard." $(726)^{1}$
}

The insuperable gap between bodily experience and discourse on the body remains the subject matter/problem of the text, which for the protagonist von der 
Schuer could be resolved in solely one way, namely in (male) collectivity, taking shape for him in policing Studentenkorps similar to paramilitary free troops.

The German sociologist, Klaus Theweleit finds the origins of the body ideology of the Nazi society in Freikorps, the free companies recreated after the First World War by demobilized soldiers and extreme right-wing volunteers. (Theweleit 2003) This paramilitary organization cooperated unofficially with the Army of the Weimar Republic carrying out policing and cleansing operations etc. Its activity served the German White Terror, which laid down the social foundations of the subsequent Nazi access to power. Although it was disbanded at the beginning of the 1920s, many of Freikorps members infiltrated into the Nazi power structures and military leadership. An analogous career history in the novel is von der Schuer's in the field of science, who became a high ranking representative of bio power. Klaus Theweleit analyses the texts of Freikorps comrades, manifestations which accommodate their personal narratives to ideology determined in social conventions and posited linguistically, in Nádas's words "measurable by social standards", that is to say, the given social standard can be gathered from them. According to this, the ideal type of male society is the soldier male (Theweleit 2003, 57) enthusing over the people and the fatherland, the comradely community, hunting and fighting, who sees the woman in an objectified form: on the one hand, he idealizes her ("white woman": mother, wife), on the other hand, he experiences her as an aggressor ("red woman": erotic femininity). He defines himself exactly as opposed to the erotic ("red") woman and flees from her to the solid block of army, nation or racial community - as Theweleit's analysis revealing the sexual motivations of the soldier male's anti-sexual attitude emphasizes. ${ }^{2}$

Nádas's two characters of the Parallel Stories - von der Schuer, the racial biologist and professor Lehr, a national ideologist and saviour of the Hungarian people - are excellent examples of this. The quality, intensity, and motifs of their ideological commitment, as well as adjustment of their private life to the scheme of "white" and "red" woman clearly illustrate the body ideology pattern demonstrated by Theweleit. Von der Schuer has a married life that maintains the race and the institution of the family - the mother of the family as virtuous and untouchable, undefilable with desire in the spirit of "white (moreover an Arya) woman" - driving his wife to a frigid existence devoid of pleasure, and himself to the scientific research of measuring erected male genital organs, among others. Professor Lehr does not look for joy in his cold marriage either, he pursues the "red woman" during his night flings, and to top it all, the most extreme version of it, who (according to Theweleit's classification) is erotic; vulgar; standing low in social/ cultural/ mental terms; a whore/ proletarian/ Jewish witch. (Theweleit 2003, 79) In the eye of Professor Lehr, the dirty, mentally or physically handicapped available incognito in the dark park is a perfect exemplar of this. However, the pattern of his wedlock is more complicated than that of his German racial 
biologist colleague: at a young age - not yet committed to the ideas of national defence - he had married a Jewish woman who could not act the part of the "white woman" ideal, but due to his alignment he identifies himself with the bio power ideology associated with the nation protecting idea so much that - almost incomprehensibly - referring to his own family declares the following: “...you bore two Jewish kids for me and now I have to suffer the consequences" (244).

Furthermore, the story of Captain Bellardi can be interpreted in the framework outlined by Theweleit, who, disappointed in love and marriage, finds shelter in an extremist nationalistic secret organization; or the story of Karla von Thum reflecting the false pattern of male society in a woman's career history. However to what extent would the case of the three spies from Budapest, Ágost Lippay Lehr, André Rott and János Wolkenstein Kovách, in the other half of the century show a different pattern? (even if slightly shifted), who do not believe this body ideology any longer, but - for want of something other - cannot escape the effect of its behaviour pattern: they are unable to establish a real connection with women, and can unwind only in their comradely-friendly community. Moreover it is not young Kristóf's inner struggle for his own sensuality - so that he can experience himself as a man (like the others) thus becoming ready for a real relationship with a woman which evolves in his homosexual adventure -, the very rejection/ mockery/reversal of this body ideology pattern?

The German sociologist examines behaviour models of comradely-military communities; Péter Nádas refers directly to male hordes in an interview where he speaks of a relevant conception produced in the novel:

\begin{abstract}
"Yes, Parallel Stories is mostly about the inner life of these male hordes. The culturally and religiously strictly prohibited, yet active, highly confidential erotic life of male hordes. Of that natural joy of footballers, driven by a sense of shared success, secretly embracing and kissing each other, as they rip their t-shirts off as if they were crazy to their audience's greatest delight. They do something their mothers, but most of all their fathers have strictly forbidden them to do over the last few centuries. [...] Different collective terror ideologies channel the same prohibited erotic energy. It is the physiological basis of all forms of racism, all kinds of exclusion and collective homicide based on all sorts of exclusion. The efforts of the representatives of Geistesgeschichste and sociologists are in vain, they will not find it where they are looking for it; these processes have an erotic basis, yes indeed." (Görözdi 2013,24)
\end{abstract}

The aspect of cultural criticism is a justified approach in the examination of the novel, applied by Enikö Darabos in her thorough analysis, who comes to the following conclusion: “...even the most radical feminists rarely venture so far into the critique of phallocentric social order, since in Parallel Stories an amazing amount of narrative variations show how the phallus organizes the symbolic order." (Darabos 2007, 451) 


\section{Body ideology and history}

Klaus Theweleit emphasizes that the twentieth century male soldier's relationship to the "white" or "red" woman is not an isolated phenomenon, but a part within a continuum of the civil patriarchy in history which seeks to secure power within male-female relations. ${ }^{3}$ Historiography does little to deal with human bodies, their experience, yet - as he writes - "until we have succeeded in reconstructing the development of our bodies in history, we will remain strangers to ourselves [...], unable to experience other bodies as equals." (Theweleit 2003, 362-363)

It seems that Péter Nádas's project in Parallel Stories seeks the same thing. Zsolt Bagi stresses the fact that the key to Nádas's depiction of body/carnality is his realism, by which the inherent language itself and the priority of searching for and creating the order expressing this are meant. In this sense, the novel is "an infinite, boundless, that is, chaotic line of the twentieth century's bodily encounters, incapable of being arranged into or told as a story." (Bagi 2015, 262) Undoubtedly, Nádas's novel establishes the European history of the twentieth century in a very specific way. Although the text can be exemplified as a genre of historical novels, the genre's definitions get notched on the text one after the other. Since the novel does not present a retroactively edited narration about the past, nor does it represent any grand national narrative or the contents of collective memory. Furthermore, it does not depict necessary assertions of political-power relations in a certain era, nor processes launched by exceptional (historical) personalities. "For the novel does not primarily refer to historical events that actually took place; not the history but the occurrence of bodily-historical experience is the main protagonist" - Sarolta Deczki writes. (Deczki 2016, 57) The novel raises a view of history different from the referred concepts, which, "within the occurrence of the bodily-historical experience" attributes role to the body and to attractions/rejections/power relations between bodies, as well as to the man vulnerable to his own sensuality and body ideologies in the evolution of history. According to Péter Nádas, history is not what historians think it is, but a "consistency" that contemporaries live through in a very individual way. (Rostás 2015) Parallel Stories - in my opinion - is a historical novel by revealing this "consistency". The "consistency" has in itself a diachronic extension but, above all, it has a synchronous feeling: a sense of leaving an impression on resp. within the human body. That is, Nádas does not follow the so-called grand history, nor does he examine how that affects the fate of some, in other words micro-history. He follows the effects in a most detailed manner : for example how Szemzőné's nerves preserve the memory of their deportation when she turns on the light against the darkness in the evenings; how the singer Gyöngyvér's rough childhood results in her vocalisation disturbance; or how Carl Döhring's body experiences are the cause of his irrational guilt in the deeds of his ascendants in concentration camps in his dreams etc. 
The technique of capturing and describing the smallest story segment is not a novelty in the Nádas prose: in A Book of Memories, for example, it is represented by a macrophotography-like momentum, a kind of frozen picture, whose true content is accomplished in a narrative. In Parallel stories, we may call the frozen bodily sensation that smallest unit whose total (or as total as possible) apprehension constitutes the stake of the narrative's credibility. In my interpretation, the Nádas history comprehended as "consistency" is assembled and gets entangled from these narratively frozen bodily sensations.

The view of history in Nádas's novel does not know hierarchy, rejects any central concepts, substance or goal principle (in theological, philosophical, social or natural scientific terms), in which an organizing principle of a hierarchy could be rooted. The events in the novel have no meaning and no purpose. "...a person does not change a bit, and without change, how can there be any progress in history." (554) - Madzar the architect contemplates. The constant question of the women from Pest who lost their fate in the maelstrom of the Second World War sounds as follow: "What should they do with their own stories and those of the others? They were all carrying their own losses, their total, all-encompassing failures. No human on earth could answer their questions, and they found no God to whom they could entrust them." (343) Dr. Schultze, carrying out eugenic measurements, approaches the question from the "diligent" science and his dilemma sounds as follows: : "Strength, energy, love, and equality are ultimately kinds of political fiction based on a statistical fiction about the average, and they have nothing to do with physics or biology."(841)

\section{Chaos-structure}

If, however, all the rules are fiction, what remains? chaos?

"Do not, indeed, the independent or interdependent, but in any case, self-contained stories interact with each other by the structures whose pattern is chaos itself?" (Nádas 2012, 84) As is well-known, the approach that the structure of Parallel Stories follows the pattern of chaos has been introduced by the author himself referring to the old Greeks, Homer, Hesiod and Ovid. (Nádas 2012, 84) However, at the structural level of the text, the chaos concept of chaos theory seems more relevant. Chaos theory describes deterministic systems sensitive to initial conditions, and in the depths of chaotic behaviour's apparent orderlessness, it gives an account of the existence of some kinds of complex geometric structures (fractal dimension), of their self-similar repetition taking place at different levels. ${ }^{4}$

In an interview, Péter Nádas gave some thought to the course of history as follows: "... I am bored of the repetitions of history, those constrains into which things are repeated over and over again. [...] behind the surface [...] of new 
situations, there are usually the same structures. The structures of life - within a nation, within a people, within a continent, for example within Europe - and the organizing principles behind the structures [...] change the least, they are usually unchanged and their ambition is to make the most varied new surfaces behind which they preserve themselves even more." (Friderikusz 2015) The idea is consistent with the concept of history the novel raises in literary adaptation. The compositional aspects of chaos with regards of the text have been dealt with by many; let us look at the nature of deep structure now.

In the depth of the apparently chaotic text of the novel, there seem to be structural repetitions that can be described, similarly to fractals, as structural tropes ${ }^{5}$, appearing in a self-similar way at different moments and stages of the plot organization and which outline some kind of a dynamic formula/pattern/model. I believe it can be captured through sensuality, which intertwines the entire novel.

The cumulative scene of the storyline in a urinal on the Margaret Island (which I consider in a sense to be the focal point of the whole work,) is actually a motion choreography with sexual content, in which bodily desires and vulnerabilities, attractions and repulsions actuate the collective changeovers, drive forward the events that are completely devoid of moral considerations. Seemingly mere materiality and instinct. However, if we succeed in seeing the scene from far enough, the changes in the order of the urinal line-up maintained by erotic tension show a complex movement structure below the surface of the events, some kind of choreographic figure of "operation" which can be found in the depths of further episodes. The horde of homosexual ruts on the Margaret Island displays the same pattern - based on male comradeship - which the aristocratic Bellardi's secret nationalistic gentlemen's society follows in the '30s or the German comrades/ military units analysed by Theweleit maintain. And which also happens among the boys in the boarding school, and even occurs among the prisoners of the concentration camp in Pfeilen. It is pleasure that is at stake in one place, the enforcement of national interests in the other, the service of homeland in the third, and survival in the fourth. Its methods here are rough, scientifically chiselled in one, and militant or unscrupulous in the other. Different manifestations in different historical circumstances, but the same deep structure. And as Theweleit's analysis reveals, this deep structure (imaging the functioning of male communities) has, indeed, ideological implications.

\section{Body and power}

The relationship between bodies and body (sensuality) ideologies also encompass power aspects, as has already been mentioned from the point of view of the civil-patriarchal historical continuity of male-female relations. In the text, Péter 
Nádas analyses this narratively. He deals with forms, intensity, direction, continuous shifting and displacement of power relations among bodies, examining this from a societal conversation through love act to crude life-death situations or bio power (eugenics as the extreme form of state-sponsored racism) that dons a science cloak and strives for the absolute dominance of bodies. He depicts all this with engineering precision and amazing sensitivity. It would be worth analysing thoroughly these very different power relations of the bodies in the novel. Similarities would most likely emerge in the mode of functioning, and mode of actions, that is, at the level of organization.

This view of power is akin to Michel Foucault's horizontal understanding of power, according to which power as such enmeshes the human society in its full width, its mechanisms primarily act flowing through the body of the individual (in their desires, thoughts and energies). The French philosopher is interested in the microphysics of the functioning of power which maintains a relationship with our sensuality and knowledge, he examines in the same way how it intrudes the sphere of the most intimate and most individual behaviour, how it keeps control of the forms of everyday activities just like Péter Nádas in his novel. This approach focuses on the body, desires, and thoughts of individuals, shaped also by power, and regards power as something that is not static and cannot be possessed, but a "moving, flowing, net-like organization". (Kelemen 2009, 142)

The bodily concept of the acting of power in society and history with Foucault as well as Nádas incorportates complicated network dynamic structures which again refer to chaos theory. From which, hereafter, I would like to raise two aspects in relation to Parallel Stories. The parts of the system that is the subject of chaos theory are self-similarly reminiscent of the whole form or its lower magnification detail. Do structural repetitions of the pattern at different levels not resemble the structure of that novel which evinces the figures, patterns, formulae of the relationship of human bodies and behaviour of communities in the most varied historical situations and under the most diverse conditions? The theory refers to deterministic systems sensitive to initial conditions, where the slightest initial alteration may cause a major change in the long-term functioning (butterfly effect) despite well-defined parameters, and this process is unpredictable, but can be calculated only per phase. Does this not relate to the novel's philosophy according to which the hope for progress, a better human world is futile, as the historical events of the twentieth century essentially mocked this, since the "organizing principles behind life structures" ${ }^{\prime \prime}$ determined the course of history more fundamentally? In fact, the thought process of one of the protagonists is strained as far as the following: "The two great paddle wheels on a single axle are spinning in place. [...] If there is no progress, there is neither past, nor future." (554) Though - thinking about the world, history and the man thrown into them, in the framework inspired by chaos theory - we might trust in the (butterfly) effect of 
minimal changes that are triggered throughout the capillaries of our complicated entanglement.

However, the author has something different to offer. In the final chapters of the novel, he launches new storylines with new locations, new characters, and little contact points to the preceding events. The interpretative endless nature of parallel stories in the novel also becomes evident to the reader. The multiplication of the storylines at the end of the text shifts the emphasis from the story (stories) in the novel to be reconstructed in parallelisms: to that analogous pattern which can be found in the "functioning" of the flashed and very different individual fates. Péter Nádas opens his opus magnum resignedly towards the reciprocally and infinitely reflected (self-similar) repetitions of the "formulae" of the deep structure.

\section{Translated by Orsolya Hegedüs}

\section{References}

Zsolt Bagi, "Realizmus: A Párhuzamos történetek és a dolgok állása," in Pontos észrevételek: Mészöly Miklóstól Nádas Péterig és vissza, ed. Zsolt Bagi (Budapest: Jelenkor, 2015), 233-266.

Sándor Bazsányi, ,....testének temploma...” Erotika, irónia és narráció Nádas Péter prózájában, (Miskolc: Mủút, 2016).

Ivan Buraj, "Michel Foucault a jeho netradičné chápanie moci," Filozofia LXI/7 (2006): 533-546. Adam Bžoch, "Péter Nádas: Paralelné príbehy," Revue svetovej literatúry XLV/4 (2009): 139-142.

Enikő Darabos, "A néma test diskurzusa: A saját mássága mint az individualitás kritériuma Nádas Péter Párhuzamos történetek című regényében,” Jelenkor L/4 (2007): 439-462.

Sarolta Deczki, “A testbe íródó történelem,” in Forditott világ (Miskolc: Mủút, 2016), 49-61.

Péter Demény, "A mindenható test világa (Nádas Péterröl)," Látó, XVIII/1 (2007).

Michel Foucault, The History of Sexuality: Volume I: An Introduction, translated by Robert Hurley (New York: Pantheon Books, 1978).

Michel Foucault, "A szubjektum és a hatalom," in Testes könyv II., ed. Kis Attila Atilla, Kovács Sándor and Odorics Ferenc (Szeged: Ictus - JATE, 1997), 267-292.

Sándor Friderikusz, "Friderikusz: Interjú Nádas Péterrel." ATV, 24 September 2015. http://www. atv.hu/belfold/20150925-nadas-peter-az-europai-gondolkodas-eloregedett [Accessed: March 6, 2018].

Judit Görözdi, "V laboratóriu písania: Rozhovor s mad’arským spisovatel’om Péterom Nádasom,” Romboid XLVIII/1 (2013): 23-30.

Csaba Károlyi, "Mindig más történik: Nádas Péterrel beszélget Károlyi Csaba," Élet és Irodalom XLIX/44 (2005).

Gábor Kelemen, "A kolonizáció hajszálerei," in A velünk élo" szenvedélyek: Szenvedélypolitika és egészségtanulás (Pécs: Pro Pannónia, 2009), 141-145.

Péter Nádas, Parallel Stories (Kindle Edition), translated by Imre Goldstein, (New York: Farrar, Straus and Giroux, 2011).

Péter Nádas, “A szerkezet és a cselekményminták," in Párhuzamos olvasókönyv, ed. Gábor Csordás (Pécs: Jelenkor, 2012), 83-84.

Péter Nádas, "Jegyzetek az égi és a földi szerelemröl," in Az égi és a földi szerelemröl (Pécs: Jelenkor, 2000), 133-158. 
Párhuzamos olvasókönyv, ed. Gábor Csordás (Pécs: Jelenkor, 2012).

Péter Nádas lesen. Bilder und Texte zu den Parallelgeschichten, ed. Daniel Graf, Delf Schmidt (Berlin: Rowohlt, 2012).

Sándor Radnóti, “Az Egy és a Sok,” Holmi XVIII/6 (2006): 774-791.

Eni Rostás, "Nádas Péter: »Nem emlékszem, hogy mikor ne lettem volna nagy munkában«" Könyves blog, 12 May 2015. http://konyves.blog.hu/2015/05/12/nadas_peter_nem_emlekszem_ hogy_mikor_ne_lettem_volna_nagy_munkaban [Accessed: March 6, 2018]

Klaus Theweleit, Male Fantasies: Volume 1: Women, Floods, Bodies, History, translated by Stephen Conway (Minneapolis: University of Minnesota Press, 2003)

\section{Notes}

1 Péter Nádas, Parallel Stories (Kindle Edition), translated by Imre Goldstein, (New York: Farrar, Straus and Giroux, 2011). The excerpts from the novel will be further quoted based on this edition.

2 Klaus Theweleit, Male Fantasies: Volume 1: Women, Floods, Bodies, History, translated by Stephen Conway (Minneapolis: University of Minnesota Press, 2003). Sándor Radnóti and Adam Bžoch also highlight the comparability of Nádas and Theweleit's concepts. Sándor Radnóti, "Az Egy és a Sok," Holmi XVIII/6 (2006): 774-791. Adam Bžoch, "Péter Nádas: Paralelné príbehy," Revue svetovej literatúry XLV/4 (2009): 139-142. For my part, I cannot identify with Theweleit's (Marxist) conclusions. However the analyses that make up the starting point of his concept which explicate the body ideology of male-female relations I also consider to be a valid and a relevant approach to Nádas's point of view .

3 The conclusions of Michel Foucault, who researched the history of sexuality, are also relevant here: he similarly derives the strategies of power and knowledge that concentrate the relations of bonds and sexuality from the 17th-18th centuries. According to him these are a hysterization of women's bodies, a pedagogization of children's sex, (an economic) socialization of procreative behaviour, and a psychiatrization of perverse pleasures. Cf. Michel Foucault, The History of Sexuality: Volume I: An Introduction, translated by Robert Hurley (New York: Pantheon Books, 1978), 104-105. Nádas on Foucault's history of sexuality: Péter Nádas, "Jegyzetek az égi és a földi szerelemröl,” in Az égi és a földi szerelemről (Pécs: Jelenkor, 2000), 122-126.

4 The author does not specifically refer to the theory of chaos, however, in his thoughts on the chaos structure of his novel, as if the complicated model of chaotic systems was outlined behind the apparent disorder: "Chaos in this case is not the mess [...] The structure is chaotic, because chaotic is the world order, in chaos I do not want to create arbitrary order, not the novelist [...] At most, I register those elements and principles that form structures in chaos and those that are unable to do such things." Csaba Károlyi, "Mindig más történik: Nádas Péterrel beszélget Károlyi Csaba," Élet és Irodalom XLIX/44 (2005). At a literary evening which took place on 29th September 2015 in the context of the conference titled A párhuzamosság szédülete [The dizziness of parallelism] organized for the translators of the novel, Péter Nádas used the broccoli metaphor for the structure of his novel which is one of the well-known examples of natural fractals.

5 Enikő Darabos makes a reference to the fractality of the novel, although her analysis follows another direction. Cf. Enikő Darabos, "A néma test diskurzusa: A saját mássága mint az individualitás kritériuma Nádas Péter Párhuzamos történetek címủ regényében,” Jelenkor L/4 (2007): 447-448.

6 Nádas's expression from the quoted Friderikusz interview. 